\title{
KUALITAS RUNNING TEXT DALAM PEMBERIAN INFORMASI DI LINGKUNGAN KAMPUS SEKOLAH TINGGI TEKNOLOGI ADISUTJIPTO YOGYAKARTA
}

\author{
Rivcky Septianto ${ }^{1}$, Sumarsono ${ }^{2}$, Hero Wintolo ${ }^{3}$ \\ 13 Jurusan Teknik Informatika Sekolah Tinggi Teknologi Adisutjipto Yogyakarta \\ 2 Universitas Negeri Islam Sunan Kalijaga Yogyakarta \\ informatika@stta.ac.id
}

\begin{abstract}
Requirement about lectures information quickly, easily, accuratelly, and cheaply. To support lectures activity, such as lectures information scedules, lectures changed scedules, and the other informations based on running text with SMS Gateway in one way. In order to increase labor produktivity, data services, and information and increase computer skills in campus suroundings or college, that needs to be pursued in service enhancement effectively and efficiently, using information technology with running text based.

In this application contains four interfaces, such as server application view, client application view, wireless fidelity (login hotspot) view, web view. Database design is a effort to make model of data management is still first draft. This database will be use to store data from the application.

The result of whole research that can be analyzing the test simulation is about mechanics work process from system over all. On the whole analyze result consist of the basic concept that built to become a system which has been discussed on the previous chapter.
\end{abstract}

Keywords: Running text, Information.

Abstrak

Kebutuhan akan informasi perkuliahan secara cepat, mudah, akurat dan murah. Untuk menunjang kegiatan perkuliahan, seperti informasi jadwal perkuliahan, perubahan jadwal perkuliahan dan informasi lainnya. Penggunaan teknologi untuk pengiriman informasi perkuliahan dan informasi lainnya yang berbasis running text dengan cara SMS Gateway yang bersifat satu arah. Dalam rangka meningkatkan produktivitas kerja, pelayanan data dan informasi serta peningkatan kemampuan komputer di lingkungan kampus atau perguruan tinggi, perlu diupayakan peningkatan pelayanan yang efektif dan efisien, dengan memanfaatkan teknologi informasi berbasis running text.

Dalam aplikasi ini terdapat empat buah interface, yaitu tampilan untuk aplikasi server, tampilan untuk aplikasi client (komputer anjungan), tampilan untuk wireless fidelity (login hotspot) dan tampilan untuk web. Perancangan database merupakan upaya untuk membuat model pengelolaan data yang masih bersifat konsep awal. Database ini akan digunakan untuk menyimpan data dari aplikasi.

Hasil dari semua percobaan dapat dianalisa dari simulasi percobaan adalah tentang proses mekanisme kerja dari sistem secara keseluruhan. Secara keseluruhan hasil analisa 
terdiri dari konsep dasar yang dibangun untuk menjadi sebuah sistem dengan apa yang telah dibahas pada bab sebelumnya.

Kata kunci : Running text, Informasi.

\section{Latar Belakang}

Di era serba digital dan serba cepat saat ini, running text atau tulisan berjalan menjadi cara penting untuk menyebarkan informasi. Running text atau tulisan berjalan seringkali dipakai sebagai sarana iklan dan promosi, media informasi di kantor, lampu merah, perbankan dan lainnya. Sistem pembaharuan (update) running text biasanya menggunakan perangkat dan program komputer dan informasi yang ditampilkan melalui running text harus sering diganti. Sebagai upaya untuk membantu meningkatkan fungsi dan layanan dan memudahkan sistem running text tersebut dengan cara membuat sistem update running text berbasis Short Message Service (SMS) yang dikirim ke aplikasi dan disimpan ke database kemudian akan ditampilkan di website, komputer anjungan dan saat login hotspot secara otomatis yang sudah terkonek dengan jaringan internet di area tersebut.

Kebutuhan akan informasi perkuliahan secara cepat, mudah, akurat dan murah. Untuk menunjang kegiatan perkuliahan, seperti informasi jadwal perkuliahan, perubahan jadwal perkuliahan dan informasi lainnya. Penggunaan teknologi untuk pengiriman informasi perkuliahan dan informasi lainnya yang berbasis running text dengan cara SMS Gateway yang bersifat satu arah. Dalam rangka meningkatkan produktivitas kerja, pelayanan data dan informasi serta peningkatan kemampuan komputer di lingkungan kampus atau perguruan tinggi, perlu diupayakan peningkatan pelayanan yang efektif dan efisien, dengan memanfaatkan teknologi informasi berbasis running text. Dalam pemanfaatan teknologi data dan informasi di lingkungan kampus dan perguruan tinggi tersebut perlu didukung oleh perangkat peraturan yang jelas dalam mengoperasionalkan pelayanan data dan informasi berbasis running text kepada mahasiswa dan masyarakat pengguna jasa informasi di kampus dan perguruan tinggi tersebut.

\section{Landasan Teori}

\section{Pengertian Sistem Terdistribusi}

Sistem terdistribusi adalah suatu kesatuan dari elemen-elemen yang saling berinteraksi secara sistematis untuk mendistribusikan data, informasi, proses, objek, dan layanan dari dan kepada pengguna yang terkait di dalamnya (Sutedjo Budi, 2006). Adapun infrastruktur utama dari aplikasi sistem terdistribusi, meliputi :

1. Jaringan komputer baik dalam skala local (LAN), metropolitan (MAN), skala luas (WAN), maupun skala global (Internet).

2. Beragam perangkat keras dan lunak, serta pengguna yang berada dan saling terkait dalam sistem jaringan yang membentuknya.

Penerapan sistem terdistribusi merupakan bentuk usaha untuk memanfaatkan secara optimal sistem jaringan komputer yang dibangun di dalam perusahaan. Sistem terdistribusi dibangun dengan tujuan :

1. Mengatasi bottleneck.

Tumpukan pekerjaan pada suatu terminal dapat didistribusikan ke terminal-terminal lain. 
2. Mendukung layanan yang terbesar.

Misalnya layanan penjualan dengan menggunakan terminal-terminal yang terbesar di berbagai tempat.

3. Mendukung sistem kerja jarak jauh.

Misalnya sistem kerja small office home office yang memungkinkan karyawan untuk bekerja dari rumah sehingga tidak harus datang ke kantor.

4. Memudahkan kerja kelompok.

Dengan memudahkan sharing data dan tetap memungkinkan kerjasama walaupun letak kelompok berjauhan.

Adapun beberapa jenis arsitektur sistem terdistribusi ialah sebagai berikut :

1. Client Server

Client menghubungi server untuk mendapatkan data, yang kemudian memformat dan menampilkan pada pengguna.

2. Tightly Coupled (Clustured)

Mesin-mesin terintegrasi yang menjalankan proses yang sama secara bersamaan dengan membagi tugas ke dalam beberapa bagian yang dijalankan masing-masing mesin. Apabila proses telah selesai, hasil pengejaan masing-masing mesin digabungkan menjadi satu.

3. Peer-to-peer

Arsitektur dimana tidak ada mesin yang menyediakan layanan atau mengelolah sumber daya jaringan sehingga segala tanggung jawab dibagikan diantara seluruh mesin.

\section{Port-Ekstensi Alamat}

Salah satu tanggung jawab umum TCP dan UDP adalah pengirim data ke protokol lapisan yang lebih tinggi. Pada cara yang sama bahwa header IP berisi alamat sumber dan tujuan, header UDP dan TCP berisi nomor port sumber dan tujuan yang mengarahkan pengiriman data ke aplikasi dan protokol diatasnya yang sesuai. Nomor port adalah ekstensi alamat. Istilah socket mengacu pada kombinasi alamat IP dan alamat port.

Aplikasi server pada jaringan IP memproses pada nomor port tertentu dan pada aplikasi client mengirimkan alamat-alamat paket ke nomor port ini. Sebagai contoh, SMTP (Simple Mail Transfer Protocol) yaitu protokol yang digunakan untuk mengirim surat elektronik, server memproses pada nomor port 25. Setiap lalulintas TCP dengan tujuan nomor port 25 secara otomatis ditujukan ke SMTP. Setiap program mail yang berkomunikasi secara langsung dengan server SMTP akan mengalamatkan segmen TCP dengan tujuan port 25. Nomor port tidaklah unik, TCP dan UDP mungkin menggunakan nomor port yang sama sebagai alamat dua aplikasi yang berbeda. Ini adalah kombinasi nomor port dan protokol yang mengidentifikasi tujuan yang tepat.

Sebagian besar aplikasi TCP/IP umum (biasanya disebut well-knows-services) berisi nomor port dibawah 256. Nomor port 1-1024 dipertimbangkan sebagai UNIX Standart Services, tetapi aplikasi yang menggunakan port ini tidak lagi eksklusif UNIX. Rentang utuh port adalah dari 1 sampai 65.535 .

Cara terbaik untuk memikirkan lalulintas IP adalah dengan membandingkannya terhadap stream. Stream memasuki komputer penerima sebagai alur datagram IP, yang semuanya berisi alamat IP penerima. Modul IP kemudian menganalisa datagram dan melewatkanya pada protokol TCP dan UDP. Ini adalah bagian pertama pada stream. Modul 
TCP dan UDP memeriksa stream mereka dan melewatkan informasi pada protokol lain lapisan yang lebih tinggi. Mekanisme dimana informasi ini diurutkan dan dipisahkan adalah alamat IP, field protokol didalam header IP, dan alamat tujuan port dengan header UDP dan TCP (Stern, 1998). Stream aliran data IP dijelaskan pada gambar 1.

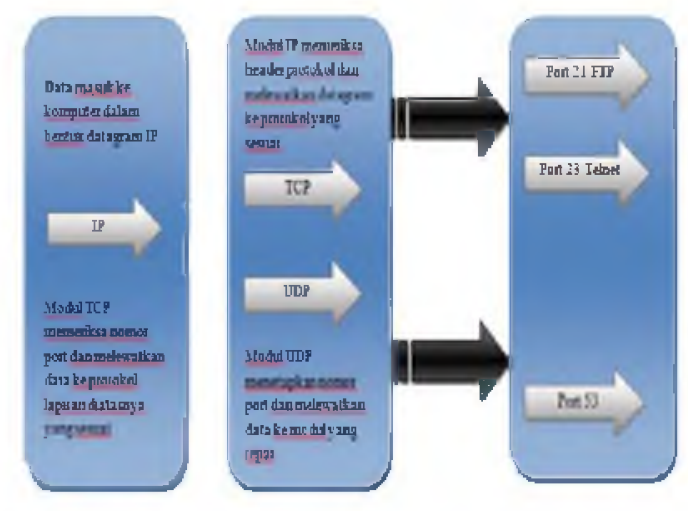

Gambar 1 Stream aliran data IP

\section{Database Server}

Database server adalah program yang digunakan untuk menyimpan data yang akan diolah di halaman web. Database biasa disebut Database Management System (DBMS) adalah sebuah aplikasi yang menjembatani user dan data-data di dalam database. Dengan menggunakan DBMS user mampu mengolah data-data di dalam database secara mudah dan tepat. Arsitektur DBMS ada yang stand alone dan ada yang client-server. Untuk aplikasi web, jenis DBMS yang digunakan adalah yang berasitektur client-server. DBMS merupakan komponen opsional dalam pembuatan aplikasi web. Maksudnya, keberadaan komponen ini di dalam komputer sangat tergantung kebutuhan dari web yang akan dibuat. Jika web tersebut menyimpan data-datanya di file dan bukan di database, maka database server tidak dibutuhkan. Sebaliknya, jika web yang dibuat butuh media penyimpanan data untuk membuat web menjadi lebih dinamis maka database server dibutuhkan. Untuk selanjutnya disebut database server. Kenapa jenis DBMS yang digunakan harus database server, karena aplikasi web adalah aplikasi client-server yang dapat diakses oleh banyak user dari berbagai tempat sepanjang ada koneksi internet. Untuk mendukung aplikasi web tersebut maka dibutuhkan aplikasi DBMS yang berasitektur client-server juga. Database server/DBMS, ada yang berbasis open source/gratis dan ada yang close source/berbayar.

Ada beberapa hal yang perlu diperhatikan ketika akan menggunakan database untuk menyimpan data-data di halaman web:

1. Jenis DBMS yang digunakan yang berbasis client-server/database server.

2. Sistem operasi yang digunakan, banyak DBMS yang dapat mendukung banyak sistem operasi.

3. Open source atau Closed source.

4. File instalasi yang dapat dipilih, apakah yang versi install (EXE) atau yang versi terkompres (ZIP/RAR).

5. Platform prosesor, apakah berbasis 32 bit atau 64 bit. 


\section{Uji Coba Dan Analisa}

\section{Uji Coba Sistem}

Uji coba sistem ini dilakukan di localhost. Uji coba dilakukan dengan menggunakan 3 buah unit komputer yang telah terhubung dalam suatu jaringan dengan bentuk topologi seperti yang tergambar dalam konfigurasi jaringan. Dari beberapa unit komputer tersebut, satu unit komputer bertindak sebagai server, komputer yang lain bertindak sebagai database dan client (komputer anjungan).

\section{Konfigurasi Jaringan}

Untuk menjalankan aplikasi ini harus dilakukan konfigurasi jaringan terlebih dahulu. Peralatan yang dibutuhkan yaitu sebuah komputer yang digunakan sebagai server dengan alamat IP 192.168.77.1, komputer yang digunakan sebagai database dengan alamat IP 192.168.77.2, komputer yang digunakan sebagai client (komputer anjungan) dengan alamat IP 192.168.77.3, dan komputer sebagai web dengan alamat IP 192.168.77.4. digunakan access point untuk menghubungkan ke client (komputer anjungan). Modem dihubungkan dengan komputer server sebagai penerima pesan atau informasi, dan sebuah handphone yang akan digunakan sebagai pengirim pesan atau informasi. Konfigurasi jaringan seperti pada gambar 2.

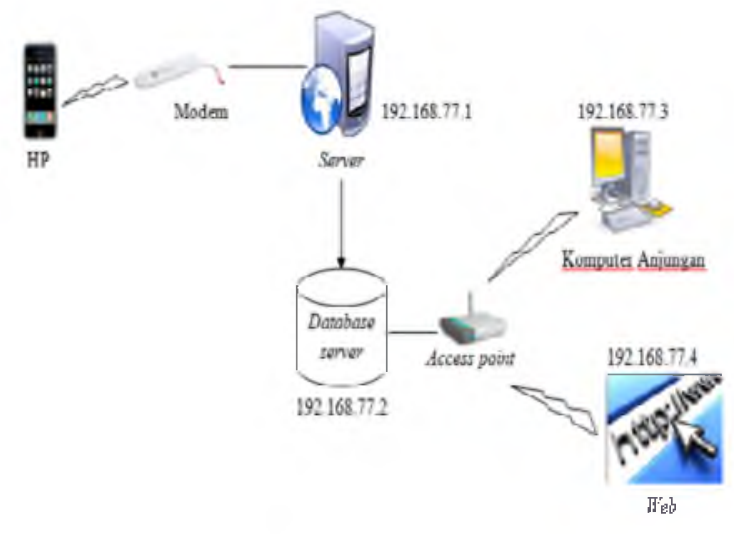

Gambar 2 Konfigurasi Jaringan

\section{Uji Coba Aplikasi Server}

Untuk dapat menjalankan aplikasi server, pengguna harus mengisikan com port yang akan digunakan untuk melakukan koneksi ke modem dengan cara modem sudah terpasang di komputer server, kemudian pengguna masuk ke my computer dengan cara klik kanan my computer, kemudian pilih manage untuk membuka halaman computer management. Selanjutnya pilih device manager, kemudian klik kanan pada nama modem dan pilih properties untuk masuk ke jendela huawei mobile connect - $3 \mathrm{G}$ modem properties, kemudian pilih menu modem untuk melihat com port yang akan digunakan untuk mengkoneksikan aplikasi server dengan modem. Cara mengkoneksikan aplikasi server dengan modem seperti pada gambar 3 . Aplikasi server siap digunakan seperti gambar 4. User/staf mengirimkan pesan atau informasi seperti pada gambar 5 . Uji coba terhadap aplikasi server dengan cara user/staf meregistrasi nama dan nomor dan mengirimkan pesan atau informasi ke aplikasi server seperti pada gambar 6. 


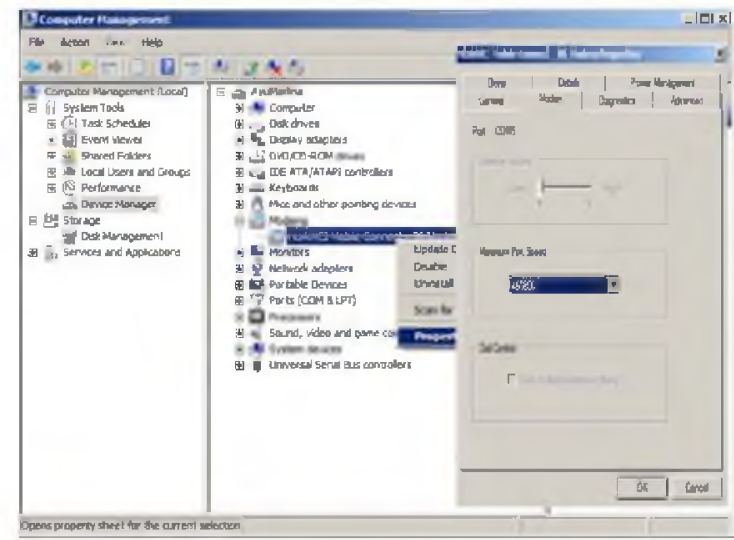

Gambar 3 Cara mengkoneksikan Aplikasi Server Dengan Modem

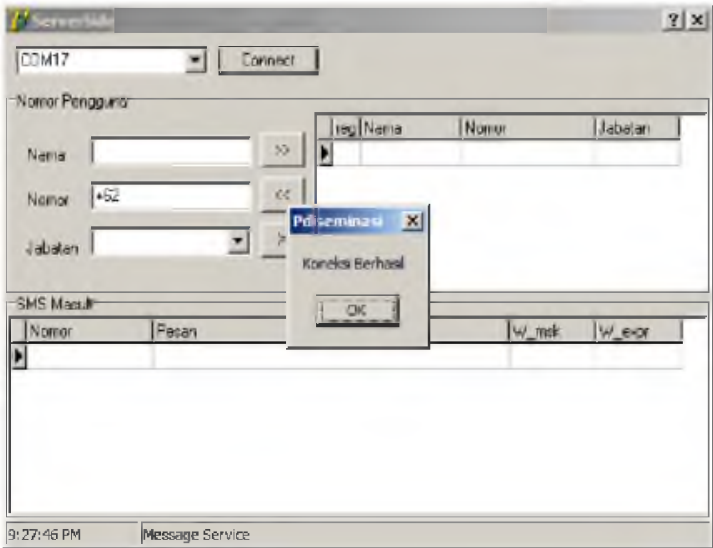

Gambar 4 Aplikasi Server Siap Digunakan

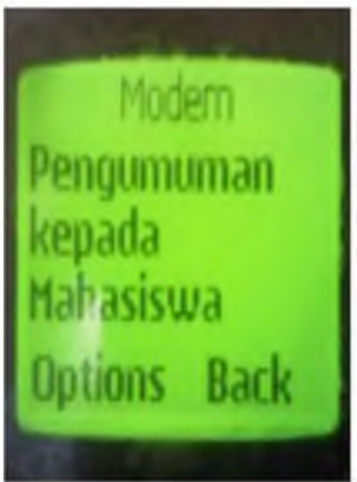

User 1

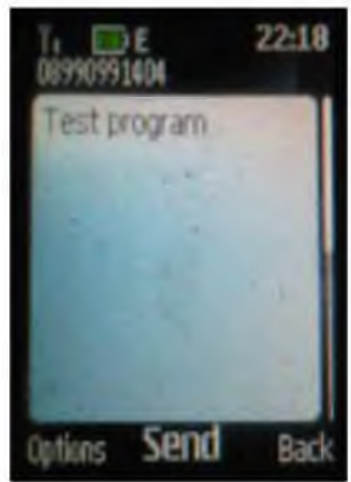

User 2

Gambar 5 Pengiriman Pesan Atau Informasi Ke Aplikasi Server 


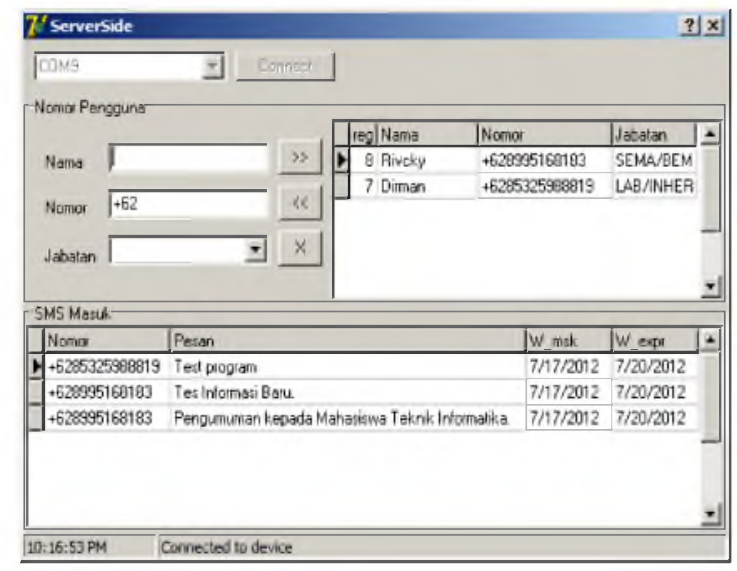

Gambar 6 Pesan Atau Informasi Yang Ditampilkan Di Aplikasi Server

\section{Uji Coba Aplikasi Client (Komputer Anjungan), Web dan Login Hotspot}

Setelah user/staf mengirimkan pesan atau informasi ke aplikasi server, maka aplikasi client (komputer anjungan), web dan login hotspot akan menampilkan pesan atau informasi tesebut. Jadi fungsi dari aplikasi client (komputer anjungan), web dan login hotspot hanya menampilkan pesan atau informasi yang dikirimkan oleh user/staf yang terdaftar di aplikasi server. Cara kerja dari aplikasi client (komputer anjungan) tersebut sama halnya dengan cara kerja web dan halaman login hotspot. Aplikasi client (komputer anjungan) tersebut menembak atau mengambil data pesan atau informasi di database yang ada di web server. Uji coba aplikasi client (komputer anjungan), web dan halaman login hotspot dapat dilihat pada gambar 7 , gambar 8 dan gambar 9 .

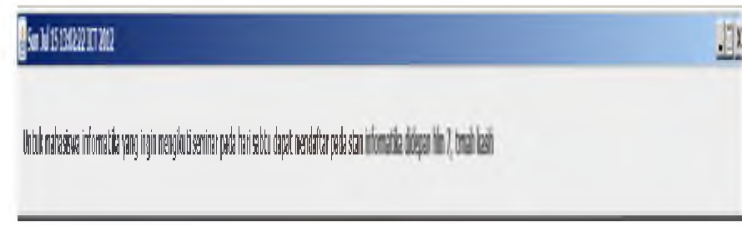

Gambar 7 Aplikasi Client (komputer anjungan) Menampilkan Informasi

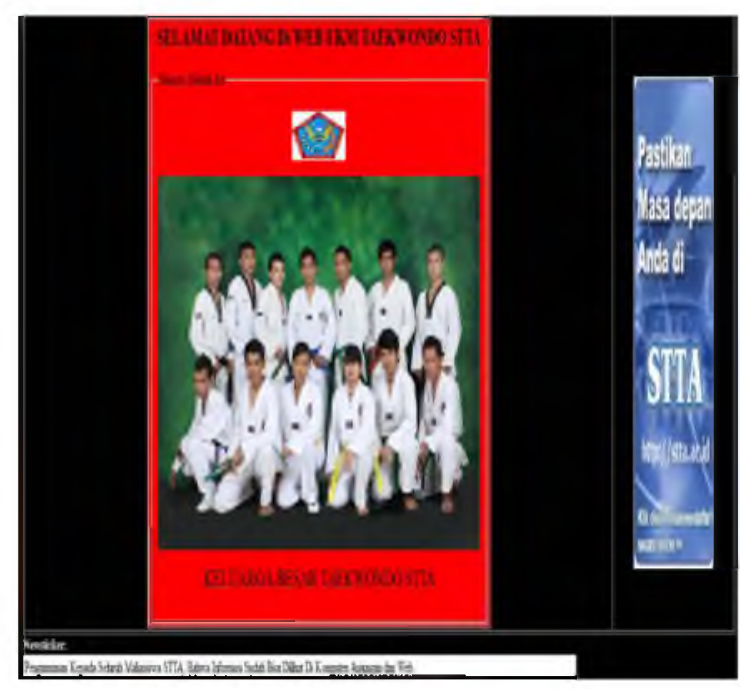




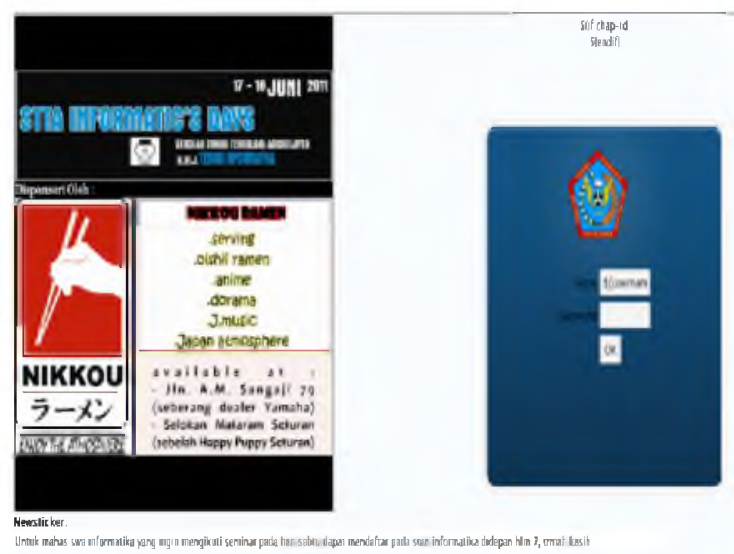

Gambar 9 Halaman Login Hotspot Menampilkan Informasi

\section{Analisa Hasil Uji Coba}

Hasil dari semua percobaan dapat dianalisa dari simulasi percobaan adalah tentang proses mekanisme kerja dari sistem secara keseluruhan. Secara keseluruhan hasil analisa terdiri dari konsep dasar yang dibangun untuk menjadi sebuah sistem dengan apa yang telah dibahas pada bab sebelumnya.

\section{Uji Provider}

Dalam melakukan uji provider ini menggunakan 5 buah sim card dari 5 provider telepon seluler yang berbeda, yaitu indosat, hutchison 3 (tri) indonesia, telkomsel, XL dan axis telekom indonesia. Tujuan dari uji provider ini yaitu membandingkan dari setiap sim card yang digunakan untuk mengetahui kecepatan pengiriman pesan. Hal ini ditunjukkan pada tabel 1 di bawah ini.

Tabel 1 Uji Provider

\begin{tabular}{|c|c|c|c|}
\hline No & Nama Provider & $\begin{array}{c}\text { Jumlah Pesan } \\
\text { Keluar }\end{array}$ & Waktu Rata-rata Pengiriman \\
\hline 1 & Indosat (IM3) & 10 & 5 detik \\
\hline 2 & $\begin{array}{c}\text { Hutchison 3 (tri) } \\
\text { Indonesia (3) }\end{array}$ & 10 & 4 detik \\
\hline 3 & Telkomsel (AS) & 10 & 4 detik \\
\hline 4 & XL (XL prabayar) & 10 & 5 detik \\
\hline 5 & $\begin{array}{c}\text { Axis Telekom } \\
\text { Indonesia (Axis) }\end{array}$ & 10 & 5 detik \\
\hline
\end{tabular}

\section{Kesimpulan}

Dari hasil pada uji coba yang dilakukan dapat ditarik beberapa kesimpulan sistem penyebaran informasi dengan memanfaatkan running text telah dapat digunakan untuk 
menyebarkan informasi secara instan dan cukup untuk mengakses informasi. Kelebihan menggunakan sistem penyebaran melalui running text adalah sebagai berikut:

a. Website dan desktop (komputer anjungan) membuat akses terhadap informasi tidak terbatas pada komputer tertentu saja.

b. Sistem dapat dengan mudah meng-update informasi dan juga memberikan akses (SMS) yang mudah kepada penginformasi (user/staf kampus).

\section{Saran}

Adapun saran yang diberikan untuk pengembangan tugas akhir ini yaitu pengembangan terhadap metode pengaksesan informasi yang tidak hanya melalui komputer tetapi juga melalui handphone ataupun perangkat lain yang memungkinkan (papan informasi digital).

\section{Referensi}

[1] Andrew S. Tanenbaum, Distributed System, Upper Saddle River, Pearson Education, 2007.

[2] Imron Romzi, Membuat sendiri SMS Gateway (ESME) Berbasis Protokol SMPP, Andi Offset, Yogyakarta, 2002.

[3] Rudyanto Arief M, Pemrograman Web Dinamis Menggunakan PHP dan MySQL, Andi Offset, Yogyakarta, 2011.

[4] Setyoadi, Wangsit., Otomatisasi Penerimaan Dan Pengiriman Pesan Dengan Sistem Terdistribusi Untuk Mendukung Penyebaran Informasi Akademik, Jurnal Compiler, Vulume I, Nomor 1, Mei 2012.

[5] Stern, Netware Untuk Koneksi Ke Internet, PT. Elex Media Komputindo, Jakarta, 1998.

[6] Sutedjo Budi., Konsep dan Aplikasi Client Server dan Sistem Terdistribusi, Andi Offset, Yogyakarta, 2006.

[7] (21 Februari 2012) http:// repository.upi.edu/skripsiview.php?no skrip.

[8] (21 februari 2012) http://www.scribd.com/doc/96584610/4-Heru-Supriyono-FatahYasin-Pengembangan-Tulisan-Berialan-h-2.

[9] (21 Februari 2012) http:/ / digilib.polsri.ac.id/gdl.php? mod=browse\&op=read\&id=ssptpolsri-gdlnurhasanah-1104\&PHPSESSID=ggggmwat.

[10] (21 Februari 2012) https://digilib.mercubuana.ac.id/ modul open file skripsi.php?ID Skripsi cover 764614701596.pdf. 